Tropical Journal of Pharmaceutical Research, October 2009; 8 (5): 393-398

(C) Pharmacotherapy Group,

Faculty of Pharmacy, University of Benin

Benin City, 300001 Nigeria.

All rights reserved.

Research Article

Available online at http://www.tjpr.org

\title{
Hypoglycemic Effects of Clitoria ternatea Linn. (Fabaceae) in Alloxan-induced Diabetes in Rats
}

\author{
P Daisy ${ }^{1}$ and M Rajathi ${ }^{2}$ \\ ${ }^{1}$ Department of Biotechnology, Holy Cross College, Tiruchirappalli-620002, Tamilnadu, \\ ${ }^{2}$ Department of Biotechnology, MVJ College of Engineering, Near ITPL, Channasandra, Bangalore-560067. \\ Karnataka, India
}

\begin{abstract}
Purpose: This study aims to investigate the therapeutic effects of the aqueous extract of Clitoria ternatea Linn. Fabaceae leaves and flowers on alloxan-induced diabetes in rats.

Methods: The effect of orally administered aqueous extracts (400 mg/kg body weight) of Clitoria ternatea leaves and flowers on serum glucose, glycosylated hemoglobin, and insulin were examined in control and extract-treated diabetic rats. The glycogen content of the liver and skeletal muscles of the rats was evaluated while the activities of the glycolytic enzyme, glucokinase, and the gluconeogenic enzyme, glucose-6-phosphatase in the liver were assessed. The extracts were administered over a period of 84 days.

Results: The aqueous extracts of Clitoria ternatea leaves and flowers significantly $(P<0.05)$ reduced serum glucose, glycosylated hemoglobin and the activities of gluconeogenic enzyme, glucose-6phosphatase, but increased serum insulin, liver and skeletal muscle glycogen and the activity of the glycolytic enzyme, glucokinase. For all the biochemical tests performed, the leaf extract-treated rat showed essentially the same profile as those treated with the flower extract.

Conclusion: The present investigation suggests that Clitoria ternatea leaf and flower extracts exhibit antihyperglycaemic effect in rats with alloxan-induced diabetes mellitus.
\end{abstract}

Keywords: Alloxan, Diabetes mellitus, Clitoria ternatea, Blood glucose, Glucose-6-phosphatase, Glucokinase, Glycogen

*Corresponding author: E-mail: santhanamaryrajathi@yahoo.co.in; Tel: +91-080-28452324; Fax: +91-08028452443 


\section{INTRODUCTION}

Diabetes mellitus is a syndrome characterized by chronic hyperglycaemia and disturbances of carbohydrate, fat and protein metabolism associated with absolute or relative deficiency in insulin secretion and/or action [1]. Insulin therapy and oral hypoglycaemic agents offer effective glycaemic control, but Insulin therapy has shortcomings such as ineffectiveness following oral administration, short shelf life, of the need for constant refrigeration, and fatal hypoglycaemia, in the event of excess dosage [2]. As a result, there is a need to search for compounds with effective antidiabetic activity when taken orally taken orally. The oral hypoglycemic agents that are capable of reducing blood sugar level belong to two chemical classes - sulfonylureas and biguanides [3]. However, the use of oral antidiabetics is limited due to their adverse side effects including hematological, cutaneous and gastrointestinal reactions, hypoglycaemic coma and disturbances of liver and kidney functions. In addition, they are not suitable for use during pregnancy [4].

Plants are well known in traditional herbal medicine for their hypoglycaemic activities, and available literature indicate that there are more than 800 plant species showing hypoglycaemic activity [5]. The World Health Organization has recommended the evaluation of the effectiveness of plants in conditions where safe orthodox drugs are scarce [6]. Studies have shown that phytochemicals isolated from plant sources have been used for the prevention and treatment of cancer, heart disease, diabetes mellitus, and high blood pressure [7].

Clitoria ternatea Linn, belonging to the family Fabaceae, is a perennial twining herb found in India, China, Philippines and Madagascar. Since the flowers of the plant resemble a conch shell, it is commonly called "Shankpushpi" in the Sanskrit language of India where it is reported to be a good "Medhya" (brain tonic) drug and, therefore, mainly used in the treatment of "Masasika" roga (mental illness). It is also useful in the treatment of severe fever, bronchitis and asthma[8]. It has been used too as an antidote for snake bite and scorpion sting [9]. The root has been used traditionally to induce abortion and its paste for curing abdominal swellings, sore throat, mucous disorders and fever [10]. A preliminary study of the fresh flowers of Clitoria ternatea showed hypoglycaemic and hypolipidaemic effects [11]. The present study was undertaken to evaluate the effectiveness of the leaf and flower extracts of Clitoria ternatea as antihyperglycaemic agents in alloxan-induced diabetic rats.

\section{EXPERIMENTAL}

\section{Plant material}

Alloxan monohydrate was obtained from Sigma Chemical Company, St. Louis, Mo, USA. All the other chemicals used were of analytical grade and were acquired from commercial sources. The leaves and flowers of Clitoria ternatea were collected from Thirumayam, Pudukkottai District, Tamilnadu, India. They were carefully identified and authenticated by Dr. Annie Xavier, Professor of Botany, Holy Cross College, Tiruchirappali - 620 002, India. The shade-dried leaves and flowers were powdered and boiled in water $(100 \mathrm{~g} / \mathrm{L}$ distilled water). The decoction was filtered through nitrocellulose filter and the filtrates were evaporated to dryness under vacuum at $50{ }^{\circ} \mathrm{C}$ in a rotary evaporator. The dried residue was stored in airtight containers pending further use.

\section{Animal studies}

Male adult Wistar strain albino rats (100-150 g) were used for the studies. Ethical approval was obtained from the Committee for the Purpose of Control and Supervision of Experiments on Animals (CPCSEA, approval no.585/05/A/CPCSEA), the institutional ethical review committee. The animals were obtained from Tamilnadu Veterinary and 
Animal Science University, Chennai, India, and fed on a standard feed (Sai Durga Feeds and Foods, Bangalore, India) and water ad libitum. The animals described as fasted were deprived of food for $16 \mathrm{~h}$ but were allowed free access to water. After randomization into groups, the rats were acclimatised to the laboratory conditions of temperature and photoperiod for a period of 1-2 weeks prior to commencement of the experiment. Diabetes mellitus was induced in a batch of normoglycaemic albino rats starved for $16 \mathrm{~h}$ by injecting intraperitoneally $150 \mathrm{mg} / \mathrm{kg}$ body weight of alloxan monohydrate dissolved in physiological saline. Since alloxan is capable of producing fatal hypoglycaemia as a result of massive pancreatic insulin release, rats were treated with $20 \%$ glucose solution intraperitoneally after $6 \mathrm{~h}$. For the next $24 \mathrm{~h}$, the rats were kept on $5 \%$ glucose solution in their cages to prevent hypoglycaemia. Seven days after alloxan injection, rats with blood glucose > $300 \mathrm{mg} / \mathrm{dl}$ were considered as diabetic and included in the study. They were divided into different groups, with five rats in each group. Aqueous extracts of the leaf (CTL) and flower (CTF) in doses ranging from $50 \mathrm{mg} / \mathrm{kg}$ body weight to $500 \mathrm{mg} / \mathrm{kg}$ body weight, at incremental doses of $50 \mathrm{mg} / \mathrm{kg}$ body weight, were administered by oral intubation to the animals, and blood glucose was estimated 5 $h$ after. The lowest dose that brought about the maximum antihyperglycaemic effect for each extract $(400 \mathrm{mg} / \mathrm{kg}$ body weight for both CTL and CTF) was selected for further studies.

In the further studies that followed, rats in which diabetes was induced as described above, were used. They were divided into three groups with ten rats in each group. One group received only distilled water while two other groups received $400 \mathrm{mg} / \mathrm{kg}$ of CTL and $\mathrm{CTF}$, respectively. A fourth group (control) consisted of normal rats that received distilled water only.

The treatments were continued daily for 84 days while normal control and diabetic control groups were given distilled water everyday for 84 days. All the treatments were by oral intubation.

At the end of the experiment, the animals were sacrificed by cervical dislocation. Blood was collected from the heart using a syringe, transferred to sodium fluoride bottles bottles, allowed to clot and the serum was separated by centrifugation at 3500 r.p.m for $10 \mathrm{~min}$. The serum was assayed either immediately or stored at $-20{ }^{\circ} \mathrm{C}$ pending assay. Commercial diagnostic kits were used to assay serum glucose (using a kit supplied by Reddy's Laboratories, Hyderabad, India), glycosylated hemoglobin (using a kit obtained from Bio Systems, Costa Brava, Spain), and insulin (using a radioimmunoassay kit from Diasorin, Italy). Tissues from the liver and skeletal muscle were collected. The glycogen contents of both the liver and skeletal muscle were estimated by the method described by Plummer[12]. Glucokinase and glucose -6-phosphatase were assayed by the method of Brandstrup et al [13]. and Baginsky et al [14], respectively.

\section{Data analysis}

The group data were statistically evaluated using the Statistical Package for Social Sciences (SPSS) version 7.5. Hypothesis testing was by one-way analysis of variance (ANOVA) followed by least significant difference test. P-values of less than 0.05 were considered statistically significant. All the results were expressed as mean \pm SD ( $n$ $=10)$.

\section{RESULTS}

As shown in Table 1, a significant increase in blood glucose and glycosylated hemoglobin and a significant decrease in serum insulin were observed in diabetic control rats when compared to normal control rats $(\mathrm{P}<0.05)$. Administration of CTL and CTF to diabetic rats significantly decreased the levels of blood glucose and glycosylated hemoglobin and at the same time increased serum insulin 
Table 1: Effect of treatment with leaf extract (CTL, $400 \mathrm{mg} / \mathrm{kg}$ ) and flower extract (CTF, $400 \mathrm{mg} / \mathrm{kg}$ ) for 84 days on serum parameters of control and diabetic rats. (Values are mean $\pm S D, n=10$ ).

\begin{tabular}{|c|c|c|c|c|}
\hline Parameter & $\begin{array}{l}\text { Normal rats } \\
\text { (Control) }\end{array}$ & $\begin{array}{l}\begin{array}{l}\text { Diabetic rats } \\
\text { (Control) }\end{array} \\
\end{array}$ & $\begin{array}{l}\text { Diabetic rats } \\
\text { treated with CTL }\end{array}$ & $\begin{array}{l}\text { Diabetic rats } \\
\text { treated with CTF }\end{array}$ \\
\hline Glucose (mg/dl) & $74.8 \pm 3.1$ & $361.0 \pm 10.4$ & $102.4 \pm 4.8$ * & $107.6 \pm 4.9$ \\
\hline Glycosylated hemoglobin (\%) & $2.44 \pm 0.29$ & $4.86 \pm 0.68$ & $2.81 \pm 0.76$ * & $2.92 \pm 0.38$ \\
\hline Insulin $(\mu \mathrm{U} / \mathrm{ml})$ & $38.6 \pm 4.5$ & $8.2 \pm 1.3$ & $30.6 \pm 2.1$ * & $29.3 \pm 2.2$ * \\
\hline
\end{tabular}

* Statistically significant when compared with diabetic controls $(P<0.05)$.

Table 2: Effect of treatment with CTL $(400 \mathrm{mg} / \mathrm{kg})$ and CTF $(400 \mathrm{mg} / \mathrm{kg})$ for 84 days on liver and skeletal muscle glycogen, and on glucokinase and glucose-6-phosphatase activities of control and diabetic rats. (Values are mean $\pm S D, n=10$ )

\begin{tabular}{lllll}
\hline Parameter & $\begin{array}{l}\text { Normal rats } \\
\text { (Control) }\end{array}$ & $\begin{array}{l}\text { Diabetic rats } \\
\text { (Control) }\end{array}$ & $\begin{array}{l}\text { Diabetic rats } \\
\text { treated with CTL }\end{array}$ & $\begin{array}{l}\text { Diabetic rats } \\
\text { treated with CTF }\end{array}$ \\
\hline $\begin{array}{l}\text { Liver glycogen }(\mathrm{mg} / \mathrm{g}) \\
\begin{array}{l}\text { Skeletal muscle glycogen } \\
\text { (mg/g) }\end{array}\end{array}$ & $49.0 \pm 1.3$ & $9.0 \pm 2.5$ & $35.0 \pm 1.0^{*}$ & $34.0 \pm 1.9^{*}$ \\
$\begin{array}{l}\text { Glucokinase }(\mu \mathrm{mol} \text { of } \\
\text { glucose-6-Po formed } / \mathrm{min} / \mathrm{mg} \\
\text { protein })\end{array}$ & $207.5 \pm 1.8$ & $1.8 \pm 0.6$ & $6.2 \pm 0.4{ }^{*}$ & $5.8 \pm 0.5^{*}$ \\
$\begin{array}{l}\text { Glucose-6-phosphatase }(\mu \\
\text { mol of Pi liberated/min/mg } \\
\text { protein) }\end{array}$ & $0.150 \pm 0.021$ & $115.4 \pm 8.9$ & $163.7 \pm 4.2 *$ & $161.0 \pm 3.2$ * \\
\hline
\end{tabular}

* Statistically significant when compared with diabetic controls $(P<0.05)$.

to near normal control levels. Table 2 shows the content of liver glycogen and skeletal muscle glycogen in control and diabetic rats. The glycogen contents of rat liver and skeletal muscle decreased in diabetic animals when compared to normal control animals but these levels increased to near normal after CTL and CTF treatment. As Table 2 also shows, the activity of glucokinase in the liver of diabetic control animals decreased while that of glucose-6phosphatase increased, compared to normal control $(P<0.05)$. However, oral administration of CTL and CTF for 84 days to the diabetic rats resulted in an increase in glucokinase activity and a decrease in glucose-6-phosphatase. However, there was no significant difference $(P<0.05)$ between the biochemical data obtained for the leaf and flower extract-treated rats.

\section{DISCUSSION}

Diabetes mellitus of long duration is associated with several complications such as atherosclerosis, myocardial infarction, nephropathy, etc [15]. These complications are usually related to chronically elevated blood glucose level. Alloxan causes a massive reduction in insulin release by the destruction of $\beta$-cells of the islets of Langerhans, thereby inducing hyperglycaemia[16]. Daily administration of the aqueous extracts of Clitoria ternatea (CTL and CTF) for 84 days resulted in decrease in the blood glucose levels of alloxan-induced diabetic rats. The possible hypoglycaemic mechanism of CTL and CTF may be through potentiation of pancreatic secretion of insulin from $\beta$-cell of islets or due to enhanced 
transport of blood glucose to the peripheral tissues.

Glycosylated hemoglobin is produced by glycosylation of hemoglobin. Glycosylated hemogolobin is formed progressively and irreversibly over a period of time and is stable over the life span of the red blood cells. It is unaffected by diet, insulin or exercise, even on the day of test. Therefore, glycosylated hemoglobin can be used as an excellent marker of overall glycaemic control. Since it is formed slowly and does not dissociate easily, it reflects the real blood glucose level[17,18]. In this study, the diabetic rats had elevated levels of glycosylated hemoglobin, and therefore, the significant decrease in the level of glycosylated hemoglobin in alloxan-induced diabetic rats following CTL and CTF therapy indicates that the overall blood glucose level was controlled, probably due to improvement in insulin secretion. It noteworthy that the serum insulin level in diabetic animals treated with CTL and CTF also increased when compared to the diabetic control animals. Thus, it seems that CTL and CTF stimulated increased insulin secretion in alloxan-induced diabetic rats. In this respect, the mode of action of these extracts is similar to those reported for extracts of Gymnema sylvestre[19], Momordica charantia[20] and Enicostemma littorale[21].

The glycogen content of skeletal muscles and liver markedly decreases in diabetes[22]. The decrease in glycogen content of liver and skeletal muscle observed in diabetic rats is probably due to lack of insulin in the diabetic state. Prevention of glycogen depletion in the liver and muscles, following the administration of the extracts, could therefore have been achieved by stimulation of insulin release[23]. Administration of CTL and CTF to the diabetic animals increased the activity of glucokinase in liver. The extract-induced decrease in the concentration of blood glucose in alloxan-treated rats may be the result of improved glucose uptake. Similar observations have been made in respect of the extracts of Catharanthus roseus[24], Tinospora cordifolia[25] and Gymnema sylvestre [26]. The activity of the gluconeogenic enzyme, glucose-6phosphatase, is usually enhanced during diabetes[27]. Following extract administration, blood glucose level fell while liver glycogen content rose. This may be due to the mobilization of blood glucose into the liver glycogen reserve. In this context, a number of plants have been reported to decreased the activity of glucose-6phosphatase in the liver of diabetic rats [28].

\section{CONCLUSION}

The results of this investigation indicate that the leaf and flower extracts of Clitoria ternatea have a hypoglycaemic effect on alloxan-induced diabetes in rats. One possible mechanism of action is increased insulin secretion and enhancement of the glycogenesis process. The extracts were effective in regulating the biochemical indices associated with diabetes mellitus such as glycogen content and the activities of glucokinase and glucose-6-phosphatase. Further studies are in progress to isolate the active principle(s) of the extracts as well as to elucidate their exact mechanism(s) of action.

\section{ACKNOWLEDGEMENT}

Financial assistance from the University Grants Commission, New Delhi, to carry out this work is acknowledged.

\section{REFERENCES}

1 Schoenfelder T, Cirimbelli TM, Citadini-Zanette V. Acute effect of Trema micrantha on serum glucose levels in normal and diabetic rats. $J$ Ethnopharmacol 2006; 107: 456-459.

2 Anuradha $K$, Hota $D$, Pandhi $P$. Investigation of central mechanism of insulin-induced hypoglycemic convulsions in mice. Indian $J$ Exp Biol 2001; 39: 500-502.

3 Trejo-Gonzalez A, Gabriel-Ortiz G, Puebla-Perez $A M$, Huizar-Contreras MD, MunguiMazariegos MR, Mella-Arreguin S, Calva E. A purified extract from prickly pear cactus (Opuntia fulginosa) controls experimentally 
induced diabetes in rats. J Ethnopharmacol 1996; 55: 27-33.

4 Alarcon-Aguilara FJ, Jimenez-Estrada M, ReyesChilpa $R$, Roman-Ramos $R$. Hypoglycemic effect of extracts and fractions from Psacalium decompositum in healthy and alloxan diabetic mice. J Ethnopharmacol 2000; 72: 21-27.

5 Rajagopal K, Sasikala K. Antihyperglycaemic and antihyperlipidaemic effects of Nymphaea stellata in alloxan-induced diabetic rats. Singapore Med J 2008; 49: 137-141.

6 World Health Organisation. Second Report of the WHO Expert Committee on Diabetes Mellitus. Technical Report Series 1980; 646: 66.

7 Waltner-Law ME, Wang XL, Law BK. Epigallocatechin gallate, a constituent of green tea, represses hepatic glucose production. J Biol Chem 2002; 277: 34933-34940.

8 Asolkar LV, Kakkar KK, Chakre OJ. Supplement to glossary of Indian Medicinal Plants with active principles, Second edition, Part I (A-K). Publications and Information Directorate (CSIR), Dr KS Krishnan Marg, New Delhi 1992: $p 217$.

9 Chopra RN, Chopra IC, Handa KL, Kapur LD. Indigenous drugs of India. Academic Publishers, Calcutta, India, 1958; $p 476$.

10 Devi BP, Boominathan R, Mandal SC. Antiinflammatory, analgesic and antipyretic properties of Clitoria ternatea root. Fitoterapia 2003; 74: 345-349.

11 Rajathi $M$, Daisy $P$. Effect of plant extracts on the blood glucose and cholesterol level of alloxan diabetic rabbits. Indian J Comp Anim Physiol 2000; 18: 14-17.

12 Plummer TD. An Introduction to Practical Biochemistry. Tata McGraw Hill Company UK, Whithington, 1987; pp 182-184

13 Brandstrup N, Kirk JE, Bruni C. The hexokinase and phosphoglucoisomerase activities of aortic and pulmonary artery tissue in individuals of various ages. J Gerontol 1957; 12: 166-170.

14 Baginsky ES, Foa PP, Zak B. Methods of Enzymatic Analysis, vol 2, 2nd edition, Bergmeyer $\mathrm{HU}$, Gawehn K, Eds, Academic Press, New York, 1992; pp 876-880..

15 Pushparaj PN, Low HK, Manikandan J, Tan BKH, Tan $\mathrm{CH}$. Antidiabetic effects of Cichorium intybus in streptozotocin induced diabetic rats. $J$ Ethnopharmacol 2007; 111: 430-434.

16 Grover JK, Vats V, Rathi SS. Antihyperglycemic effect of Eugenia jambolana and Tinospora cordifolia in experimental diabetes and their effects on key metabolic enzymes involved in carbohydrate metabolism. J Ethnopharmacol 2000; 73: 461-470.

17 Bunn HF, Gabbay KH, Gallop PM. The glycosylation of hemoglobin: relevance to diabetes mellitus. Science 1978; 200: 21-27.
18 Bunn HF. Evaluation of glycosylated hemoglobin in diabetic patients. Diabetes 1981; 30: 613-617.

19 Shanmugasundaram KR, Paneerselvam $C$, Samudram $P$, Shanmugasundaram ERB. The insulinotropic activity of Gymnema sylvestre, an Indian medical herb used in controlling diabetes mellitus. Pharmacol Res Communications 1981; 13: 475-486.

20 Cakici l, Hurmoglu C, Tunctan B, Abacioglu N, Kanzik I, Sener B. Hypoglycemic effect of Momordica charantia extracts in normoglycemic or cyprohepatidine-induced hyperglycemic mice. $J$ Ethnopharmacol 1994; 44: 117-121

21 Maroo J, Vasu VT, Aalinkeel R, Gupta S. Glucose lowering effect of aqueous extract of Enicostemma littorale Blume in diabetes: a possible mechanism of action. $J$ Ethnopharmacol 2002; 81: 317-320.

22 Vats V, Yadav SP, Grover JK. Effect of Trigonella foenum graecum on glycogen content of tissues

and the key enzymes of carbohydrate metabolism. J Ethnopharmacol 2003; 85: 237242.

23 Chakrabarti S, Biswas TK, Rokeya B, Ali L, Mosihuzzaman $M$, Nahar $N$, Khan AKA, Mukherjee B. Advanced studies on the hypoglycemic effect of Caesalpinia bonducella in type 1 and type 2 diabetes in Long Evans rats. J Ethnopharmacol 2003; 84: 41- 44.

24 Singh $S N$, Vats $P$, Suri $S$, Shyam R, Kumria MML, Ranganathan $S$, Sridharan $K$. Effect of an antidiabetic extract of Catharanthus roseus on enzymic activities in streptozotocin-induced diabetic rats. $J$ Ethnopharmacol 2001; 76: 269-277.

25 Prince PSM, Menon VP. Hypoglycemic and other related actions of Tinospora cordifolia roots in alloxan-induced diabetic rats. $J$ Ethnopharmacol 2000; 70: 9-15.

26 Shanmugasundaram $K R$, Paneerselvam $C$, Samudram $P$, Shanmugasundaram ERB. Enzyme changes and glucose utilization in diabetic rabbits: the effect of Gymnema sylvestre. J Ethnopharmacol 1983; 7: 205234.

27 Babu PS, Ignacimuthu S, Prince PSM. Restoration of altered carbohydrate and lipid metabolism by hyponidd, a herbomineral formulation in streptozotocin-induced diabetic rats. Asian $J$ Biochem 2008; 3: 90-98.

28 Sachdewa A, Khemani LD. Effect of Hibiscus rosa sinensis $L$ ethanol flower extract on blood glucose and lipid profile in streptozotocininduced diabetes in rats. $J$ Ethnopharmacol 2003; 89: 61-66. 